\title{
The European Union Directive on the application of patients' rights in cross-border healthcare. Could it be part of the Global Health Summit strategy?
}

\author{
Alceste Santuari \\ Department of Sociology and Business Law, University of Bologna, Bologna, Italy \\ E-mail: alceste.santuari@unibo.it
}

Received 7 September 2021

Accepted 29 December 2021

\begin{abstract}
.
BACKGROUND: Member States (MSs) retain the powers to arrange their own national health care systems. However, EU has progressively developed an important co-ordination role. Such an institutional and legal framework has had a significant impact on how citizens' right to health is dealt with at the European level.

OBJECTIVE: The article intends to prove that the greater the cooperation among MSs the better for citizens' right to health. METHODS: EU law - Directive 2011/24/EU.

RESULTS: The Rome Declaration highlights the importance of all-of-society and health-in-all-policies approach. This underlines the "strategic" importance of the right to health.

CONCLUSIONS: The Rome Declaration may contribute to identifying public health not only as an individual, fundamental right but also as an obligation on both EU and Member States to ensure that right.
\end{abstract}

Keywords: Health care system, EU citizenship, cross-border health care

\section{Introduction}

The Rome Declaration, which was agreed upon on 21st May 2021, at the end of the Global Health Summit of 21st May 2021, includes 16 principles.

Principle No. (3) invites all governments to foster all-of-society and health-in-all-policies approaches, "with mutually reinforcing national and community elements, and promote responsibility at the highest levels of government for the achievement of better preparedness, prevention, detection and response".

To grasp the implications of the abovementioned statement for the European Union some references to the special legal framework that defines the relationships between the Union and its Member States are needed. 


\section{Public health between EU and Member States' powers}

It is noteworthy that public health falls within single Member States' powers and that accordingly the province of EU institutions in health care-related matters is somehow limited. Hence, the European institutions are allowed to take on subsidiary or coordination actions only [Art. 168, par. 1, Treaty on the Functioning of the European Union]. The Union has only then a supportive, coordinative and supplementary role [Article 6 TFEU]. Also Article 168 para. 7 TFEU emphasizes the responsibilities of the Member States for the definition of their health policy and for the organisation and delivery of health services and medical care. Only for common safety concerns in public health matters, there is a shared competence between the Union and the Member States [Article 4 para. 2 lit. k TFEU].

It is national and regional/local governments' responsibility to make up decisions upon the organisation, management and, especially, financing of their own health care systems. Since Member States are in charge of protecting the financial stability of their national systems, they are responsible to ensure adequate planning of health care infrastructure and capacity.

However, this could hold to the extent that citizens would search for health provisions and services at home. In fact, over the last decades, especially due to the increase in the freedoms of economic establishments and movement of people across the different Member States, a new awareness concerning public health as an "European subject-matter" has slowly but progressively arisen.

\section{Public health and freedom of movement}

The increasing freedom of movement of people within the EU has also brought with it an increase in the potential demand for health services abroad [In 2019, a total of 115,459 enquiries were made across the 27 National Contact Points providing data. European Commission, Member State Data on cross-border health care following Directive 2011/24/EU, year 2019, p. 15].

The main reasons why EU citizens may be wanting to obtain health treatments and services elsewhere in the EU are as follows:

(a) The treatment/service/provision is not available in the patients' home country;

(b) the provision/treatment/service supplied abroad is regarded to be of a better quality than in the patient's home country;

(c) the treatment/service/provision is delivered by a well renowned specialist;

(d) the treatment/service/provision is faster and cheaper abroad than in the patient's home country.

Yet, the abovementioned positive reasons are often overshadowed by other factors that prevent EU citizens from seeking cross-border health care. They are the following: more convenience to be treated near home, satisfaction with health care at home, lack of information about availability and quality of treatment abroad, language barriers, and finally lack of financial means.

A further factor for the shortage of patient mobility is represented by health budget restraints that Member States have taken on as one of the consequences of the international financial crisis of $2007 / 2008$. 


\section{The 2011 Directive relating to patients' right to cross-border health care}

To strengthen EU citizens' willingness to access cross-border health care, Directive 2011/24/EU on the rights of patients to cross-border health care aims to make EU citizens free to move across Europe to access health care services and provisions. Although public health falls under single Member States' powers, this Directive has entitled EU citizens the right to "belong" to a kind of "European health care system".

Over the last decades, the Court of Justice of the European Union often ruled that such a right is to be recognised as a fundamental right of any EU citizen despite their affiliation with single Member States' national health care systems.

The Court's rulings, which were largely incorporated in the Directive's legal provisions, on the one hand, confirmed Member States' responsibility in the organisation and supply of health care provisions and services. On the other hand, they stated that patients are free to move cross-border to access health care services. Such an approach has paved the way to the progressive recognition that despite Member States' financial responsibility in keeping health budgets under strict control, EU citizens may be regarded as European patients. This implies that, under given circumstances and conditions, any EU citizen is free to access cross-border health care.

Since Directive 2011/24/EU could not make public health a European shared subject-matter, it made it a right to be recognised to all EU citizens-patients. Such a recognition implies that not only are all Member States' welfare and health care systems to be prepared to match the demands of the population that is insured within their own welfare systems. They also have to set up services and provisions for patients who are affiliated to other welfare systems in the European Union.

In this respect, Directive 2011/24/EU provides that EU citizens-patients are free to access cross-border health facilities, services and provisions being certain about the costs they incurred and complying with less administrative procedures. In this respect, the Directive of 2011 provides for the obligation of national welfare system of affiliation to cover the expenses that patients incurred abroad. This means that once the health care services or provisions are included in the national health basket, they can be obtained abroad too and can be reimbursed by the national welfare system.

Directive 2011/24/EU also repealed the "prior authorisation requirement" that had defined the previous system. Accordingly, once the health treatment, provision or service sought abroad falls within patients' national health basket, they are entitled to access cross-border health care.

\section{The main provisions of Directive 2011/24/EU}

However, Directive 2011/24/EU distinguishes between hospital and non-hospital services as far as prior authorisation system is concerned. Since hospital care services are known to be cost intensive, Member States usually require prior authorisation for such services. However, the Directive provides that the requirements according to which prior authorisation is to be granted are to be proportional and based on objective, non-discriminatory criteria [see ECJ ruling in Müller-Fauré and van Riet, C-385/99, EU:C:2003:270, para. 83-5: "Objective, non-discriminatory criteria which are known in advance, in such a way as to circumscribe the exercise of the national authorities' discretion, so that it is not used arbitrarily"; "based on a procedural system which is easily accessible and capable of ensuring that a request for authorisation will be dealt with objectively and impartially within a reasonable time and refusals to grant authorisation must also be capable of being challenged in judicial or quasi-judicial proceedings"]. 
The prior authorisation system is based on planning: national, regional or local health authorities plan the number of hospitals, their geographical distribution, the way in which they are organised and the facilities with which they are provided as well as the medical services offered [see ECJ ruling in MüllerFauré and van Riet, C-385/99, EU:C:2003:270, para. 77 and 80: "The hospital care sector generates considerable costs and must satisfy increasing needs, while the financial resources which may be made available for health care are not unlimited"].

By contrast, non-hospital care is expected to be regarded as "prior authorisation" free since the level of planning and financial implications are lower than in the case of hospital care. This implies a wider freedom of choice on the part of citizens/patients that are expected to find more possibilities to access cross-border health care.

\section{The value of Directive 2011/24/EU}

Over all, the Directive strikes a fair balance between the citizens' rights to move freely cross border to access health care services and the need for the Member States to control over their health budgets. Yet, the specific power that Member States retain in the organisation, management, production, supply and financing of their national welfare systems often represent an obstacle to patients' freedom of crossborder movement.

Accordingly, a few questions arise: might one state then that patients' rights to access health care services depend upon Member States' budgets? Are we facing a time in which the principle that defines many legal systems, especially European ones, according to which "everyone is entitled to access health care services regardless their wealth" is about to give way to financial sustainability? In the light of the pandemic, how will cross-border health care be influenced? Will it be definitely be hindered by COVID-19 related health restrictions?

\section{Directive 2011/24/EU and the Rome Declaration}

The Rome Declaration seems to offer some positive responses to the abovementioned questions. To start with, public health should be separated from people's specific economic and financial conditions. Public health is to remain a fundamental right, which any citizen is entitled to. Member States' single health care systems should be encouraged to take action to strengthen, widen and promote public health provisions and services. Although some health care services might be subjected to some limited users' fees, health care provisions should maintain their universal coverage.

Secondly, health care systems need more investments and better governance. Investments are to channelled both through public bodies and private organisations. The pandemic has stressed the importance of creating and strengthening welfare systems in which public authorities and private entities, both forprofit and non-profit, establish effective, sustainable and durable public-private partnerships. As far as governance is concerned, it too needs to be revised and reframed to make it more inclusive, multilevel and patient-centred. In particular, it has been clear that public authorities need to engage private organisations not only in the provision of health care services but also in their projecting and programming.

In this respect, the idea that health care systems are to be regarded only as expensive pieces of the modern welfare states that need to be reduced in order to ensure financial sustainability is to be overcome. Since the priority of all priorities must be the protection of citizens' right to access health care services, financial sustainability must follow. This implies a vision according to which health care systems' financial resources and priorities of actions are bound together. The former cannot hinder the latter: on the contrary, 
both national health care systems and the European pattern are expected to pool enough financial resources to ensure that all EU citizens may be entitled to free, universal and effective health care services.

Thirdly, particular attention should be devoted to the legal and organisational patterns by which health care services are provided. There is a direct link between the citizens' right to access health care services and the way these are planned, performed and carried out. In this respect, the dramatic consequences of COVID-19 have witnessed to the actual need to deploy an effective command chain through which national authorities may coordinate with regional and local health authorities to make their responses more rapid and timely.

Fourthly, European freedoms need a comprehensive legal interpretation framework. They include both freedom of providing and freedom of receiving services [see ECJ ruling in Luisi and Carbone, joined cases 286/82 and 26/83, EU:C:1984:35, para. 16], which represent the two sides of the same coin. Freedom of providing services implies that Member States are to commit themselves to providing and delivering health care services and provision without any undue delay [see ECJ ruling in Elchinov, C-173/09, EU:C:2010:581, para. 65]. The notion of undue delay (e.g. due to waiting lists) cannot be depending on administrative criteria. It has to be based on individual medical assessment [see ECJ ruling in Elchinov, C-173/09, EU:C:2010:581, para. 66: "The competent institution is required to have regard to all the circumstances of each specific case and to take due account not only of the patient's medical condition at the time when authorisation is sought and, where appropriate, of the degree of pain or the nature of the patient's disability which might, for example, make it impossible or extremely difficult for him to carry out a professional activity, but also of his medical history"], where necessary even after a re-examination [see ECJ ruling in Watts, C-372/04, EU:C:2006:325, para. 69] of the state of health of the patient concerned (patient-centred perspective). Consequently, it can be seen as a balanced solution that confirms Member States' competence to provide healthcare, but it limits it on a timescale, if a certain treatment cannot be provided in due time because of specific shortcomings.

\section{What about Member States' powers in light of the pandemic?}

Member State's competence is also respected insofar as they can set lists of medical services paid for by their social insurance system (definition of "health basket") [see ECJ ruling in Smits and Peerbooms, C-157/99, EU:C:2001:404, para. 87; ECJ judgment in Müller-Fauré and van Riet, C-385/99, EU:C:2003:270, para. 98: "It is for the Member States alone to determine the extent of the sickness cover available to insured persons"]. This competence is limited too insofar as such lists have to be drawn up in accordance with objective criteria [see ECJ ruling in Smits and Peerbooms, C-157/99, EU:C:2001:404, para. 89] and have to be non-discriminatory [see ECJ ruling in Smits and Peerbooms, C157/99, EU:C:2001:404, para. 95: "Independent where the providers of treatment are established"]. As a matter of fact, Member States are allowed to make coverage dependent on what national professional circles might regard as most appropriate from a medical point of view. However, a purely national perspective is no longer enough insofar as the international state of the art ("what is sufficiently tried and tested by international medical science") has to be taken into account [see ECJ ruling in Smits and Peerbooms, C-157/99, EU:C:2001:404, para. 94, 97]. In this respect, it is irrelevant if the list of benefits for which the national legislation provides does not expressly and precisely specify the treatment method applied, but defines types of treatment [see ECJ ruling in Elchinov, C-173/09, EU:C:2010:581, para. 73]. In addition, it is not possible to simply presume that the hospital treatment that cannot be given in the Member State on whose territory the insured person resides, is not included in the benefits for which 
reimbursement is provided for by the legislation of that State [see ECJ ruling in Elchinov, C-173/09, EU:C:2010:581, para. 73]. In a similar way, also in this context we can observe a balanced approach, as the ECJ refers not only to well-established principles of EU law (objectivity, non-discrimination), but combines national competence with international medical state-of-the-art.

The combination between national powers, medical and scientific evidence and freedom of movement leads to ascertain that Member States may not introduce or maintain unjustified restrictions of the exercise of fundamental freedoms in the area of health care. Likewise, however, public health ranks foremost among the assets or interests protected by EU Treaties. This implies Member States' responsibility to decide upon the degree of the protection that they intend to afford to public health and upon the way in which that degree of protection is to be achieved.

Yet, Member States' decisions cannot be detrimental for citizens/patients' own health demands, because the way they might rule the organisation of their own health care system could be somehow against EU law.

\section{The Charter of Fundamental Rights of the European Union and the future of citizens' demand for cross-border health care}

In this respect, it is noteworthy that Article 35 of the Charter of Fundamental Rights of the European Union states as follows: "Everyone has the right of access to preventive health care and the right to benefit from medical treatment under the conditions established by national laws and practices. A high level of human health protection shall be ensured in the definition and implementation of all the Union's policies and activities."

While the wording of the provision of Article 35 clearly refers to individuals' rights, the explanations only refer to "principles set out in this Article" [Explanations relating to the Charter of Fundamental Rights, O.J. 2007 C 303, p. 17 (27)]. Yet since Article 6 para. 1 TEU provides that the Charter "shall have the same legal value as the Treaties" [see Hervey, T. and McHale, J., 'Article 35 - The Right to Health Care', in S. Peers, T. Hervey, J. Kenner and A. Ward (eds.), The EU Charter of Fundamental Rights: A commentary (Oxford: Hart Publishing, 2014), pp. 951-68 (967)] its wording must considered as essential.

Article 35 neither creates rights against the EU, nor creates additional rights against Member States. It rather extends the scope of nationally guaranteed rights to cross-border health care services. Therefore, Article 35 should be regarded as providing for an obligation on Member States to enforce the contents of the Charter [see ECJ ruling in Åkerberg Fransson, C-617/10, EU:C:2013:105, para. 21]. This definitely involves the enjoyment of the passive freedom of (healthcare) services by EU citizens [see Hervey, T. and McHale, J., 'Article 35 - The Right to Health Care', in S. Peers, T. Hervey, J. Kenner and A. Ward (eds.), The EU Charter of Fundamental Rights: A commentary (Oxford: Hart Publishing, 2014), pp. 951-68 (951-2)].

The EU institutions and the Member States' national welfare systems have had to confront both the prolonging negative effects of the 2007/2008 international financial crisis and the dramatic burdens of the current pandemic. The financial crisis pushed the whole of Europe to adopt austerity policies, which ended up with reducing (i.e. cutting) health care services and the right of citizens to access them.

In this respect, cross-border health care witnessed a significant setback in a general context in which the challenges are both economic and demographic [see I. Begg, F. Muschoevel, R. Niblett, The Welfare State in Europe. Visions for Reform, Research Paper, Chatham House, The Royal Institute of International Affairs, London, September 2015]. The austerity policies also brought with them an increase in the level 
of co-payment of health care services by patients, the re-arrangement of hospital organisation and of other health providers, increase of the time in waiting lists, both for visits and surgical operations. Economic and welfare state crisis as well as austerity policies have made it rather difficult for MSs to ensure the same standards of care and the same values they were used to provide in the past.

Overall, Member States have faced many problems in promoting solidarity and equity in accessing health care [see Zsuzsanna Jakab, WHO Regional Director for Europe. Health systems in times of global economic crisis: an update of the situation in the WHO European Region, Oslo, Norway, 17 April 2013]. Consequently, the right to healthcare at home has overshadowed the right to cross-border access [See CJEU, C-617/10 ruling of 26th February 2013].

By contrast, the pandemic seems to have triggered a sort of general reaction that has favoured both more investments in health care organisation and provisions and more attention to how health care services are to be supplied, especially at the local level. On the one hand, the Next Generation EU programme provides for significant investments to be used by Member States to amend, improve and strengthen their own health care and welfare systems. On the other hand, Member States themselves have been called upon to set up strategies, actions and plans whereby to make their health care systems more effective, sustainable and resilient.

Finally, the Rome Declaration may contribute to identifying public health not only as an individual, fundamental right but also as an obligation on both EU and Member States to ensure that right. The recent Next Generation EU financial programme and the Italian National Resilience and Recovery Plan are excepted to increase the quality, the accessibility, the affordability and, ultimately, the entitlement of health provisions and services including cross-border care.

\section{Conflict of interest}

None to report. 